\title{
The Effect of Working Capital Management on Performance of Small Enterprises in Kenya
}

\author{
Mwirigi Douglas $^{1}$ (MBA), Hannah Wanjiku Wambugu ${ }^{2 *}\left(\right.$ PhD), Mary Maina ${ }^{3}($ PhD) \\ ${ }^{I}$ School of Business Administration, Kirinyaga University \\ ${ }^{2}$ School of Business Administration and Economics, Kirinyaga University \\ ${ }^{3}$ School of Business and Economics, Kirinyaga University
}

*Corresponding Author: Hannah Wanjiku Wambugu, School of Business Administration and Economics, Kirinyaga University

\begin{abstract}
Small enterprises have played a critical role in provision of employment, goods for export, income to the government and general value addition. Nevertheless, they face myriad of challenges in managing working capital. The study evaluates the effect of working capital management on the performance of Small Enterprises in Kenya. The research aims at establishing the effect of working capital management-Cash conversion cycle, Inventory turnover days, accounts payable days and accounts receivable days on financial performance of Small Enterprises. Net profit was used as the basis of determining the financial performance of the Small Enterprises. The study investigated small enterprises with more than ten employees in Kirinyaga County. The study used both cross-sectional and correlational research design to determine the effect and relationship between the independent and dependent variables. The study population was Small Enterprises within the county from which a sample of 40 firms used and was obtained through simple random sampling. Questionnaires were administered to the owners of each selected SMEs in order to obtain the primary data. The data obtained was analyzed using multiple regression model to examine the effect of working capital management on the performance of Small Enterprises. The results indicates that's the accounts payable had a positive but insignificant effect on the profit made by SMEs (Coefficient 742.855, p-Value 0.478). Accounts receivable had a negative but insignificant effect on the profit made by SMEs (Coefficient -2977.465, p-Value 0.399). Inventory management had a negative but significant effect on the profit made by SMEs (Coefficient 38445.823., p-Value 0.013). The study concludes that managers can increase profits through shortening Inventory turnover and accounts receivable days. Moreover they can increase profitability through negotiating for better credit terms with their suppliers so that they are able to increase accounts payable days since longer account payable days has positive effect on profitability
\end{abstract}

Keywords: Accounts Payable, Accounts Receivable, Inventory Management.

\section{INTRODUCTION}

Small and medium enterprises are vital driving forces towards economic promotion as they contribute to economic development of any country (Terziovski, 2010). According to Carson (2011) Small Enterprises are nurturing ground for entrepreneurship culture; provide employment and goods for export. Globally, the small and medium enterprises have had a great impact in the economic growth in various countries but face innumerable working capital management allied challenges. In Switzerland, the Small and Medium Enterprises segment accounts for $23 \%$ of the total employment and value addition of $25 \%$ representing about $4 \%$ of the business population (Nakos \& Brouthers, 2017). Even so, the small enterprises have pitiable working capital management approaches principally in management of cash conversion cycle and trade payables. In European Union countries such as Norway, Cohen \& Kaimenakis (2017) observed that Small Enterprises account for 99\% of all the enterprises and about two thirds of the total employment.

Despite the benefit, Management of working capital was among the main challenges that SMEs stumble upon. In smaller countries in Europe such as Denmark, Finland and Norway, Small Enterprises are an imperative source of employment and gross value addition (Cohen \& Kaimenakis, 2017). There is a conjoint singularity noted by Cohen \& Kaimenakis (2017). They observed that SMEs have poor financial management strategies and challenges in making liquidity decision. In 
Germany, they account for $43 \%$ of the GVA and overall employment of 34\% (Shin \& Soenen, 2008). Nevertheless, SMEs poorly manages their accounts payable and receivable.

In Africa, the potential of the Small Enterprises has not yet been fully tapped. In sub-Saharan Africa, the small and medium enterprises (Small Enterprises) are critical drivers of growth across the economies accounting for almost $90 \%$ of the businesses in these markets (Biggs \& Shah, 2006). In Kenya, the Small Enterprises contributed about 3\% of the GDP. They constitute 98 percent of all businesses according to the recent national economic survey by the central bank (CBK, 2017). In addition, the SME sector creates 30 percent of jobs per annum and a contribution of $3 \%$ to the GDP.

The economic survey undertaken in 2014 shows that 80 percent of the 80,000 jobs created in that year emanated from the informal sector (Bowen, Morara \& Mureithi, 2016). The micro-enterprises have an average turnover of 500,000 and less than 10 employees (KBS, 2017). The small and medium enterprises dominate the Kenyan market and they are found in city estates and along major highways. Despite this immense contribution and great potential in the Small Enterprises, the industry lacks effective financial management (Bowen, Morara \& Mureithi, 2016). Major Small Enterprises fail at an early stage due to lack of proper management. Upon growth, profitability and liquidity decisions challenge the owners while conducting day to day operations. The managers are always in dilemma of achieving profitability and liquidity tradeoff while at the same time maximizing the value of the firm.

Despite the immense contribution of the Small Enterprises to the economy, various researches indicate that Small Enterprises suffer from various constrains which limit their resilience to risk and limit growth towards attainment of the economies of scale (Mburu, 2010). These challenges include working capital management, financial investment among others. Besides, lack of management capacity, credit worthiness, ability to secure finances and poor investment decisions affect performance (Januaris, 2015).

A review of the local studies points out that management of working capital is critical in any firm despite the industry and size. Oluoch (2017) analyzed effects of working capital on performance of non-financial companies listed in NSE, Kenya. He found that there was minimal relationship between working capital management and profitability of the non-financial companies listed in NSE. Mburu (2010) also conducted a study on the relationship between working capital management and profitability among the insurance companies. He succinctly found a strong relationship between working capital management and profitability of the insurance firms. Githinji (2013) conducted a study on working capital management and firm profitability empirical evidence from construction and manufacturing firms listed on NSE. He found out that there was insignificant positive relationship between working capital management and financial performance of manufacturing and construction firms listed at the NSE. Nthiwa, Nzioki, Riwo\&Kimeli (2013) conducted a study on management of working capital and its effect on profitability of the Manufacturing companies listed on NSE, Kenya. They found an insignificant relationship between profitability and inventory turnover. Nonetheless, they noted a positive correlation between average payment period and average collection period with profitability.

Januaris (2015) conducted a study on the effect of working capital management on profitability of public listed energy companies in Kenya. He found that short cash conversion cycle was more profitable and had significant effect on profitability. From the above studies, little has been done on the Small Enterprises in Kenya County as major researchers concentrate on the large scale producing companies listed in NSE. There is a need to establish the effect of working capital management and its impact on performance of Small Enterprises in Kenya.

The objective of this study is to evaluate the effect of working capital management on the performance of Small Enterprises with more than 10 employees in Kenya. Specifically, the study seeks to address the following objective:

- To examine the effect of cash conversion cycle on the performance of Small Enterprises in Kenya

- To evaluate the effect of accounts receivable days on the performance of Small Enterprises in Kenya

- To examine the effect of inventory turnover days on the performance of Small Enterprises in Kenya 
- To examine the effect of accounts payable days on the performance of Small Enterprises in Kenya

This study contributes to the scholarly knowledge, industry practitioners and policy formulators interested in the performance of Small Enterprises in Kenya. Scholarly, the research tested the theory of the relationship between working capital management and firms' performance. To the policy formulators and industrial practitioners- the county governments and non- governmental organizations supporting Small Enterprises in Kenya- can use the knowledge generated to understand the dynamics of the Small Enterprises working capital management and develop policies that are likely to help Small Enterprises develop working capital management literacy.

This research is an eye opener for researchers interested in Small Enterprises. It offers background knowledge on the working capital management and its contribution to performance of the Small Enterprises.

\section{Methodology}

The study used both cross-sectional and correlational research design to determine the effect and relationship between the independent and dependent variables. The study population was Small Enterprises within the county from which a sample of 40 firms used and was obtained through simple random sampling. Questionnaires were administered to the owners of each selected SMEs in order to obtain the primary data. The data obtained was analyzed using multiple regression model to examine the effect of working capital management on the performance of Small Enterprises in Kirinyaga County.

\section{LITERATURE REVIEW}

\subsection{Theoretical Literature}

\subsubsection{Inventory Turnover in Days}

Inventory turnover is defined as the number of days taken by a firm to convert materials into finished goods. This ratio represents or indicates the efficiency of managing inventory. Poor sales and excess inventory is shown by a low inventory turnover ratio as affirmed by Ruichao (2013). Nonetheless, contradictory research outcomes have been observed over time. Raheman and Nasr (2007); Gill, Biger and Marthur (2012); Mathuva (2010) found that inventory turnover and profitability have a positive relationship. According to the research, maintenance of sufficient levels of inventory reduces interruptions that might occur during the production process and losses from scarcity of the products. Nonetheless, investing excessively in stock ties-up capital that would otherwise be invested in activities that generate revenue (Mugo, 2016). Strategic management of inventory contributes to business profitability. Ruichao (2013) claims that knowing how long each item of stock remains before being sold and knowing how quickly the stock is moving is key to manage inventory.

\subsubsection{Cash Conversion Cycle}

Cash conversion cycle is a measure that is widely used to evaluate the risks and returns associated with management of liquidity (Gorondutse, Ali, Abubakar \& Naalah, 2017). According to Napompech (2012) every corporate organization is concerned greatly on how to improve and sustain profitability. In the contemporary competitive environment, sustainability of the businesses remains subject to the ability and success of financial management function. According to (Nthiwa, Nzioki, Riwo \& Kimeli, 2013) efficient management of the cash conversion cycle provides a surety on the long run survival of the business.

In a manufacturing company, the cash conversion cycle is expressed as

$$
\text { days inventory outstanding + Days Sales outstanding - Days payable outstanding }
$$

The accounts receivable days are determined as $\left(\left(\frac{\text { accounts receivable }}{\text { sales }} \times 365\right)\right)$ (Nakos \& Brouthers, 2017). It measures the average number of days a business takes from the sale of goods on credit to collection from the accounts receivables.

According to Napompech (2012) Inventory conversion is determined as: $\frac{\text { inventory }}{\text { cost of goods sold }} \times 365$.

Inventory conversion cycle shows the amount of time taken by a firm to convert raw materials into finished goods. Lastly, payable deferral time is the amount of time that a firm takes or is needed to 
acquire goods on credit and make the final payment (Oluoch, 2017). It's expressed as $\left(\frac{\text { accounts payable }}{\text { costofgoods sold }} \times 365\right)$ the impact of the inventories, accounts receivable and accounts payable on the profitability of the business is measured using cash conversion cycle. Besides, it aids in management of current assets and measuring performance of a firm (Oluoch, 2017). While long-term assets or the fixed assets can be leased to reduce cost of acquiring new asset or investment, current assets such as receivables and inventories cannot be leased or rented.

As an alternative valid measure of liquidity, the concept of cash conversion cycle matches with the cash management principle (Rehman\& Takumi, 2012). This means collecting cash as soon as possible, putting available cash to the best use when available and postponing cash outflow as long as possible. According to Saunders (2003) the period of time or the length of the firm cash conversion cycle is subject to the length of the production process, the duration of time it takes to pay credit to its suppliers and lastly the average period of time taken to collect debts from customers.

The length of the cash conversion cycle is instrumental in determining the extent at which the firm or business relies on external borrowing as a source of finance. Accounts payable is a spontaneous credit generated by a business in its normal operations (Terziovski, 2010). Accounts payable has no interest expense or explicit financing charge as long as late payment doesn't attract charges. Increase in the number of sales possess a great financing challenge to the business as they are required to finance operations to meet the rising demand (Rehman\& Takumi, 2012). This is affirmed by Waweru (2013) who noted that a firm with slow turnover of inventory, accounts receivable and anemic gross profits finds that even little expansion or growth needs external financing. According to Carson (2011) one of the primary causes of bankruptcy is long cash conversion cycle especially in instances where profit margin is low.

In addition to determination of external financing, cash conversion cycle is closely related to the issues of firm valuation. Bowen, Morara \& Mureithi (2009) while studying the relationship between working capital management and the profitability of the Small Enterprises found out that the present value of the net cash flows generated by assets is higher when the cash conversion cycle is shorter. This translates to a higher value of the firm. In like manner, the liquidity of the firm is high when the cash conversion cycle is shorter. This is based on the fact that deferred payments which act as a free source of finance offsets the number of day's cash is tied up in capital.

\subsubsection{Accounts Receivable Days}

Accounts receivable is the amount of money owed to a company springing from the sale of goods on credit. According to Amyx (2005) the accounts receivables are determined by the business credit collection policy and the level of total sales. According to Deloof (2003) credit policy involves four critical variables which include collection policy, credit standards, early payment discounts, and credit period. The most critical decision at the discretion of the business in terms of receivables is determining the period of time between sales and credit collection and the amount of credit extended to the customers. According to Gorondutse, Ali, Abubakar\&Naalah (2017) credit terms have a direct effect on the revenue generated from the receivables and associated cost. A tight policy inhibits investment in accounts receivable which result to minimal bad debt losses but at the same time reduce profits and lower sales (Johnson \&Soenen, 2003). By establishing and applying scientifically based system of managing accounts receivables and establishing a sound credit policy, a business can make satisfactory profit and return on investment.

As aforementioned, there three primary issues that are prevalent in management of accounts receivable. Procedure used to collect the money, terms of credit and who to extend credit (Lazaridis\&Tryfonidis, 2006). Extending credit should be under the basis of cost and benefits due to the uncertainty engrossing future payment. Being one of the components of cash collection cycle, average credit days is determined by; $\frac{\text { accounts receivable }}{\text { average credit sales per day }}$.

This ratio measures the duration of time taken by business to convert credit sales into cash (Matambalya\& Wolf, 2001). It defines the relationship between cash flows and accounts receivables. Higher degree of investment in accounts receivable is indicated by longer average collection period. This in turn translates to less cash available to meet cash outflows due to high investment in accounts receivable. 
Mekonnen (2011) established statistically a negative relationship between business profitability and the average collection period. Based on this finding, it can be deduced that the profitability of a firm can be improved by reducing credit days. In addition, the replenishment of the inventory is a function of cash. The more the cash is available the higher the ability of the firm to replenish the stock resulting to higher sales. Lazaridis and Tryfonidis (2006) established a negative relationship between profitability and average collection period. This means increasing the number of credit days by a single day results to decline in business returns. Various researchers established that bad debts increased with increase in debt collection days. Thus the chances of firm losing credit money are higher when the collection period is higher.

\subsubsection{Accounts Payable Days}

Accounts payable is a liability that is derived from the purchase of goods on credit. Extending period of payment could increase the profitability of the business (Avlonitis\&Salavou, 2007). Nonetheless, deferment of payments has the ability to damage the credit reputation of the firm and alternatively affect the profitability of the business negatively in the long run (Mugo, 2016). Delaying payment to suppliers provides enough duration of time for the businesses to access the quality of the products. In addition, it's a flexible source of financing and it's inexpensive. Nonetheless, Mwangi, Makau, Kosimbei (2013) noted that the implicit cost derived from the late payment as the business foregoes early payment discounts.

\subsection{Empirical Review}

Gorondutse, Ali, Abubakar and Naalah (2017) analyzed the effect of working capital management on Small Enterprises profitability in Malaysia. They established a positive effect of cash conversion cycle on net operating profit. In addition, the study showed a positive effect of day's accounts payable on the overall returns of Small Enterprises from net operating profit. The study concluded that the profitability of Small Enterprises in Malaysia depended on how effective they manage their working capital.

Sajid (2013), studied working capital management and performance of SME sector in Pakistan. He specifically investigated the impact of the WCM on profitability of Small Enterprises, relationship between debt and profitability and the relationship between liquidity and profitability. He found out that cash management has a positive relationship with the profitability of the Small Enterprises. Nonetheless, collection period, CCC, and inventory turnover have inverse relationship with performance. While analyzing the size of the variable, he found out that there exists a positive relationship between growth in sales and profitability. In contrast, $\mathrm{He}$ found out that debt ratio exhibits a negative effect on profitability. Empirically, research has confirmed aggressive working capital management policies maximize the profitability ratio of firms. Particularly, findings of Mburu (2010) provide substantial evidence that there is a significant relationship between working capital management variables: cash, payables, account receivables and inventories with profits of the small and medium enterprises. Based on her findings, working capital management requirements decides the profitability and liquidity of a firm which in turn affect the investment and financing decisions of an organization.

Napompech (2012) established that the strategic competitiveness of a business can be increased by shortening inventory conversion period, cash conversion cycle, and receivables collection period. Nonetheless, he observed that profitability cannot be increased by lengthening the deferral period. Lastly the study established that characteristics of an industry have an impact on the gross operating profits. Johnson and Soenen (2003) reported that management of the working capital efficiently resulted to financial flourishment of the firms.

While analyzing a sample of Belgian firms, Deloof (2003) found out that shortening inventory conversion and the receivable collection period could raise their performance. He noted that there is a negative relationship between duration of time for accounts payable and financial ability. This confirms the Wang (2002) findings which established that poorer firms prolong the duration of paying debts. While analyzing a sample of Taiwanese and Japanese firms, Lazaridis and Tryfonidis (2006) they found out that shortening the cash conversion cycle enhances performance of the firm. Erasmus (2010) found out that there is a significant negative relationship between net trading cycle and profitability.

While analyzing the relative importance of the working capital management and its component to Small Enterprises profitability, Tauringana, Venancio and Godfred (2013) established that 
management of the accounts receivable and payables is important for Small Enterprises profitability. Nonetheless, they noted that management of the accounts payable is relatively more important than the management of the accounts receivable. He further established that cash conversion cycle and inventory management is not important for Small Enterprises profitability. However, according to questionnaire, the perception is that management of the cash conversion cycle and its components is perceived as critical for Small Enterprises strategic competitiveness. Under the basis of importance, they established that accounts receivable, accounts payable, inventory and cash conversion cycle follows each other in the order of importance.

Rehman and Nasr (2007) undertook a study in Karachi India to establish the relationship between profitability and components of watching capital among profitable enterprises in the city. They laid emphasize on the study of cash conversion cycle, the inventory turnover period, the average collection period, and current ratio. The study established that there is a negative relationship between the variables and the net operating profit. This means that the profitability decreased with increase in the cash conversion cycle. A negative relationship between liquidity and profitability was established.

A study by Kyalo (2011) observed that working capital management is a critical instrument of success for any business. According to the study, prudent management of the working capital management enhances strategic competitiveness by increasing firm's profitability. In addition, the efficient management of the working capital will enhance growth of the firm's market share, industry lifecycle and its progress in production. Mwangi et al. (2013) investigated the effect of the working capital management on the performance of the non-financial companies listed in the NSE (Nairobi stock exchange) established that working capital management policies have an effect on the strategic competitiveness of these firms.

Nzioki et al. (2014) while analyzing the effects of working capital management on the profitability of the NSE listed firms. He established that there is a positive correlation between profitability and average payment period and collection period but a negative correlation with cash conversion cycle. Further he established that the relationship between inventory turnover in days and profitability was insignificant. While analyzing the effect of working capital management on firm's profitability in Kenya for the period between 2003 and 2012, Makori and Jagango (2012) established that negative relationships exist between number of days of account receivable and cash conversion cycle and profitability. Conversely, they found out that inventory turnover and payables turnover have a positive correlation with profitability. Besides, they pointed out that management of a firm can create value to the shareholders by reducing the number of days of account receivable. The firm can take a longer period of time to pay creditor provided it doesn't strain or affect the relationship between the two.

\section{RESUlts OF THE REgRESSION MODEL}

\begin{tabular}{|c|c|c|c|c|c|c|}
\hline \multicolumn{7}{|c|}{ Coefficients } \\
\hline \multirow{2}{*}{\multicolumn{2}{|c|}{ Model }} & \multicolumn{2}{|c|}{ Unstandardized Coefficients } & \multirow{2}{*}{$\frac{\text { Standardized Coefficients }}{\text { Beta }}$} & \multirow[t]{2}{*}{$\mathbf{t}$} & \multirow[t]{2}{*}{ Sig. } \\
\hline & & B & Std. Error & & & \\
\hline \multirow[t]{4}{*}{1} & (Constant) & 419493.112 & 78590.634 & & 5.338 & .000 \\
\hline & $\begin{array}{l}\text { Number of days taken to } \\
\text { pay creditors }\end{array}$ & 742.855 & 1036.591 & .111 & .717 & .478 \\
\hline & $\begin{array}{l}\text { Number of days taken to } \\
\text { collect cash from Debtors }\end{array}$ & -2977.461 & 3486.933 & -.129 & -.854 & .399 \\
\hline & $\begin{array}{l}\text { Inventory management in } \\
\text { days }\end{array}$ & -38445.823 & 14725.602 & -.403 & -2.611 & .013 \\
\hline
\end{tabular}

According to the results, $\mathrm{R}^{2}=.206$ which means $20.6 \%$ changes in profit can be explained by elements of working capital management. The significance of this model was tested using $\mathrm{F}=$ test which shows that $\mathrm{F}=(3,36)=3.113, \mathrm{p}=.038$. The $\mathrm{p}$ value is below .05 which means the model is significant. The results indicates that's the accounts payable had a positive but insignificant effect on the profit made by SMEs (Coefficient 742.855, p-Value 0.478). This implied that, holding all other factors constant, the amount of profits is expected to be higher by 742.855 Kenya Shillings if the days to pay creditors are increased by one day. Accounts receivable had a negative but insignificant effect on the profit made by SMEs (Coefficient -2977.465, p-Value 0.399). This implied that, holding all other factors constant, the amount of profits is expected to be lower by 2977.465 Kenya Shillings if the days to collect debts are increased by one day. The results indicated that, inventory management had a negative but significant effect on the profit made by SMEs (Coefficient -38445.823., p-Value 0.013). 
This implied that, holding all other factors constant, the amount of profits is expected to be lower by 38445.823 Kenya Shillings if Number of days it takes to convert raw materials to finished materials is increased by one day.

The model is as follows:

\section{PER = 419493 -38445IT+742 AP - 2977AR + 78,590 $\mu$}

Where:

PER= performance (profit)

IT- Inventory Turnover

$\mathrm{AP}=$ Accounts Payable (days)

$\mathrm{AR}=$ Accounts Receivable (days)

According to the regression model obtained, the average profit for small enterprises is 419,493 all factors held constant. 78,590 is the standard error term. Cash Conversion Cycle was omitted from the model because it was highly correlated to the dependent variable (profit).

\section{CONCLUSIONS AND RECOMMENDATIONS}

From the results, it can be conclude that longer accounts payable period has positive effect on the profitability of business. On the other hand, longer inventory management periods has negative effect on profitability of SMESs. Longer accounts receivable days has negative effects on profitability of SMEs. The study concludes that managers can increase profits through shortening Inventory turnover and accounts receivable days. Moreover they can increase profitability through negotiating for better credit terms with their suppliers so that they are able to increase accounts payable days since longer account payable days has positive effect on profitability.

The managers and owners of small enterprises should strive to minimize the period of time it takes to convert raw materials into finished goods. Stock controlling should be done to avoid excessive stocking or over production which will result to high holding cost. Besides, firms should concentrate on increasing demand and production that matches the demand. Anything below or above this will result to underproduction or over production respectively. Inventory turnover has a statistically significant effect and managers should give maximum attention to it.

Although cash conversion cycle is highly related to profitability, thus dropped from the regression analysis, managers should work on strengthening it. This can be achieved by shortening inventory turnover days, accounts payable days and accounts receivable days. Shortening inventory turnover days will increase firms profit while shortening accounts payable days and receivable days will reduce bad debts and improve firm's liquidity.

Small enterprises should also establish a positive relationship with creditors by shortening their accounts payable days. It should be noted a single alteration of an element of working capital management will result to a change in all other elements. By increasing movement of stock, the enterprises will be able to pay creditors earlier and thus strengthen their liquidity.

Small enterprises should also diligently follow up debts, appraise customers before giving debts, provide incentives for early debt payments and develop a strong debt management policy in order to improve their accounts receivables and eliminate bad debts but at the same time increasing sales and inventory turnover.

\subsection{Recommendations for Further Study}

This research has dwelt on only a few elements of working capital management in which it has established insignificant relationship between profits and accounts receivable days, cash conversion cycle and accounts payable days. Besides, it has established a significant relationship between profit and inventory turnover days. More research can be done to unearth the cause of this insignificant relationship between these elements of working capital management and profits. Further research can also be done on other elements of working capital management and try to establish their effect on performance of small enterprises.

\section{REFERENCES}

[1] Amyx, C. (2005). Small business challenges-The perception problem: Size doesn't matter. Washington Business Journal, 10(3), 39-57. 
[2] Avlonitis, G. J., \&Salavou, H. E. (2007). Entrepreneurial orientation of Small Enterprises, product innovativeness, and performance. Journal of Business Research, 60(5), 566-575.

[3] Baumol, W. J. (1972). On taxation and the control of externalities. The American Economic Review, 62(3), 307-322.

[4] Biggs, T., \& Shah, M. K. (2006). African SMALL ENTERPRISES, networks, and manufacturing performance. Journal of banking \& Finance, 30(11), 3043-3066.

[5] Bowen, M., Morara, M., \&Mureithi, M. (2009). Management of business challenges among small and micro enterprises in Nairobi-Kenya. KCA journal of business management, 2(1).

[6] Carson, D. (2011). Some exploratory models for assessing small firms' marketing performance (A qualitative approach). European journal of marketing, 24(11), 8-51.

[7] Central Bank of Kenya (CBK). (2017) Small Enterprises Annual Report 2017, Nairobi.

[8] Cohen, S., \&Kaimenakis, N. (2007). Intellectual capital and corporate performance in knowledge-intensive Small Enterprises. The Learning Organization, 14(3), 241-262.

[9] Cooper, D. R., Schindler, P. S., \& Sun, J. (2006). Business research methods (Vol. 9). New York: McGraw-Hill Irwin.

[10] Deloof, M. (2003). Does working capital management affect profitability of Belgian firms?.Journal of business finance \& Accounting, 30(3-4), 573-588.

[11] Deloof, M. (2003). Does working capital management affect profitability of Belgian firms?.Journal of business finance \& Accounting, 30(3-4), 573-588.

[12] Erasmus, P. D. (2010). Working capital management and profitability: The relationship between the net trade cycle and return on assets. Management Dynamics: Journal of the Southern African Institute for Management Scientists, 19(1), 2-10.

[13] Garengo, P., Biazzo, S., \&Bititci, U. S. (2005). Performance measurement systems in Small Enterprises: A review for a research agenda. International journal of management reviews, 7(1), 25-47.

[14] Gorondutse, A. H., Ali, R. A., Abubakar, A., \&Naalah, M. N. I. (2017). The effect of working capital management on Small Enterprises profitability in Malaysia. Polish Journal of Management Studies, 16.

[15] Gul, S., Khan, M. B., Raheman, S. U., Khan, M. T., Khan, M., \& Khan, W. (2013). Working capital management and performance of SME sector. European Journal of Business and management, 5(1), 60-68.

[16] Johnson, R., \&Soenen, L. (2003). Indicators of successful companies. European management journal, 21(3), 364-369.

[17] Juan García-Teruel, P., \& Martinez-Solano, P. (2007). Effects of working capital management on SME profitability. International Journal of managerial finance, 3(2), 164-177.

[18] KYALO, K. W. (2011). Relationship between working capital management and profitability of cement companies in Kenya (Doctoral dissertation, University of Nairobi).

[19] Lazaridis, I., \&Tryfonidis, D. (2006). Relationship between working capital management and profitability of listed companies in the Athens stock exchange.

[20] Makori, D.M., \&Jagongo, A., (2013). Working Capital Management and Firm Profitability: Empirical Evidence from Manufacturing and Construction Firms Listed on Nairobi Securities Exchange, Kenya. International Journal ofAccounting and Taxation, 1 (1).

[21] Man, T. W., Lau, T., \& Chan, K. F. (2002). The competitiveness of small and medium enterprises: A conceptualization with focus on entrepreneurial competencies. Journal of business venturing, 17(2), $123-142$.

[22] Matambalya, F., \& Wolf, S. (2001). The role of ICT for the performance of Small Enterprises in East Africa: empirical evidence from Kenya and Tanzania (No. 42). ZEF Discussion Papers on Development Policy.

[23] McCartney, K., Burchinal, M. R., \& Bub, K. L. (2006). Introduction to the monograph. Monographs of the Society for Research in Child Development, 71(3), 1-8.

[24] Miller, M. H., \& Orr, D. (1966). A Model of the Demand for Money by Firms. The Quarterly journal of economics, 80(3), 413-435.

[25] Mugenda, O. M. \&Mugenda AG (2003). Research Methods, Qualitative and Quantitative Approaches.

[26] Mugo, A. N. (2016). Challenges Facing Kenyan Micro and Small Enterprises in Accessing East African Markets: A Case of Manufacturing Mses in Nairobi (Doctoral dissertation, United States International University-Africa).

[27] Mwangi, L.W., Makau, M.S., Kosimbei, G., (2013). Effects of Working Capital Management on Performance of Non- Financial Companies Listed In NSE, Kenya. European Journal of Business and Management. 6 (11).

[28] Nakos, G., \&Brouthers, K. D. (2017). Entry mode choice of Small Enterprises in Central and Eastern Europe. Entrepreneurship Theory and Practice, 27(1), 47-63. 
[29] Napompech, K. (2012). Effects of Working Capital Management on theProfitability of Thai Listed Firms. International Journal of Trade, Economics and Finance, 3(3), 227.

[30] Ngechu, M. (2004). Understanding the research process and methods. An introduction to research methods. Unpublished MBA Thesis, School of Business: University of Nairobi.

[31] Nthiwa, J. M., Nzioki, P. M., RiwoAbudho, M., \&Kimeli, S. K. (2013). Management of working capital and its effect on profitability of manufacturing companies listed on Nairobi securities exchange (NSE), Kenya.

[32] Nzioki, P.M., Kimeli, S.K., Abudho, M.R., \&Nthiwa, J.M. (2013). Management of working capital and its effect on profitability of manufacturing companies listed on Nairobi securities exchange (NSE), Kenya. International Journal of Businessand Finance Management Research. IJBFMR 1, 35-42.

[33] Oluoch, J. O. (2017) The Impact of Cash Management Practices on Performance of Small Enterprises: A Survey of Small Enterprises in Eldoret Central Business District.

[34] Orser, B. J., Hogarth-Scott, S., \& Riding, A. L. (2000). Performance, firm size, and management problem solving. Journal of Small Business Management, 38(4), 42.

[35] Pasanen, M. (2003). In search of factors affecting SME performance. University of Kuopio, Kuopio.

[36] Raheman, A., \& Nasr, M. (2007). Working capital management and profitability-case of Pakistani firms. International review of business research papers, 3(1), 279-300.

[37] Rehman, A., \& Takumi, H. (2012). Determinants of dividend payout ratio: Evidence from Karachi Stock Exchange (KSE). Journal of Contemporary Issues in Business Research, 1(1), 20-27.

[38] Saunders, P. (2003). Social theory and the urban question. Routledge.

[39] Shin, H. H., \&Soenen, L. (2008). Efficiency of working capital management and corporate profitability. Financial practice and education, 8, 37-45.

[40] Tauringana, V., \&AdjapongAfrifa, G. (2013). The relative importance of working capital management and its components to Small Enterprises' profitability. Journal of Small Business and Enterprise Development, 20(3), 453-469.

[41] Terziovski, M. (2010). Innovation practice and its performance implications in small and medium enterprises (Small Enterprises) in the manufacturing sector: a resource-based view. Strategic Management Journal, 31(8), 892-902.

[42] Waweru, E. W. (2013). Challenges of financial management affecting performance of small and medium enterprises in Nairobi (Doctoral dissertation).

\section{AUTHORS' BIOGRAPHY}

Dr Mary Maina, Currently a faculty member in the school of Business and Economics, Kirinyaga University. She holds a PhD (Finance Option)

Dr Hannah WanjikuWambugu, Currently a Lecturer and Dean School of Business and Economics, Kirinyaga University. She holds a PhD in Business Administration (Marketing Option)

Mwairigi Douglas, Did his undergraduate studies and Master degree at Kirinyaga University. $\mathrm{He}$ specializes in Finance, and he is also a CPA K holder

Citation: Hannah Wanjiku Wambugu, et.al. "The Effect of Working Capital Management on Performance of Small Enterprises in Kenya". International Journal of Managerial Studies and Research (IJMSR), vol 6, no. 12, 2018, pp. 1-9. doi: http://dx.doi.org/10.20431/2349-0349.0612001.

Copyright: (C) 2018 Authors. This is an open-access article distributed under the terms of the Creative Commons Attribution License, which permits unrestricted use, distribution, and reproduction in any medium, provided the original author and source are credited. 